\title{
Influence of Microbial Phytase on Tibia Characteristics and Biochemistry in Blood Serum of Broiler Chickens
}

\author{
Ebrahim Mohammed Hussein Alarasi ${ }^{*}$ and R.K. Pandey ${ }^{2}$ \\ ${ }^{1}$ Department of Animal Husbandry and Dairying, Institute of Agricultural Sciences, Banaras \\ Hindu University, Assistant Professor in Department of Animal Husbandry, Faculty of \\ Agriculture and Veterinary Medicine, University of Thamar, Yemen \\ ${ }^{2}$ Department of Animal Husbandry and Dairying, Institute of Agricultural Sciences, Banaras \\ Hindu University, Varanasi-221005, India \\ *Corresponding author
}

\begin{tabular}{|c|c|}
\hline & A B S T R A C T \\
\hline & \multirow{5}{*}{$\begin{array}{l}\text { Two hundred ten }(210) \text { of one day old commercial broiler chicks (VenCobb } 500) \text { were } \\
\text { divided into five }\left(\mathrm{T}_{0}, \mathrm{~T}_{1}, \mathrm{~T}_{2}, \mathrm{~T}_{3} \& \mathrm{~T}_{4}\right) \text { groups of } 42 \text { birds in each with three replicate of } 14 \\
\text { broilers in each with the aim to see the effect of microbial phytase enzyme on the tibia } \\
\text { characteristics and biochemistry in blood serum of broilers. For said purpose, the birds of } \\
\text { (T1, T2, T3\&T4) groups were feed with basal diets having ( } 250 \mathrm{FTU}, 500 \mathrm{FTU}, 750 \mathrm{FTU} \text { \& } \\
1000 \mathrm{FTU} / \mathrm{kg} \text { ) respectively, while T0 group was feed without any phytase. The experiment } \\
\text { was conducted for one day to } 42 \text { days and the birds of } \mathrm{T}_{4} \text { group having significantly } \\
(\mathrm{p}<0.05) \text { higher percentage of tibia characteristics such as dry weight, calcium, phosphorus } \\
\text { and zinc of broiler chickens and also the biochemistry such as calcium and phosphorus in } \\
\text { blood serum of broilers. Thus, the results show that the phytase enzyme having better } \\
\text { effect on the tibia characteristics and biochemistry in blood serum of broilers. } \\
\text { Aforementioned trial was carried out in summer seasons. }\end{array}$} \\
\hline Keywords & \\
\hline $\begin{array}{l}\text { Phytate, Microbial } \\
\text { phytase, Tibia and } \\
\text { broiler performance. }\end{array}$ & \\
\hline Article Info & \\
\hline $\begin{array}{l}\text { Accepted: } \\
\text { 20 September } 2017 \\
\text { Available Online: } \\
\text { 10 November } 2017\end{array}$ & \\
\hline
\end{tabular}

\section{Introduction}

Phytate is the major form of phosphorus found in cereal grains, beans and oilseed meals feed to poultry birds. Approximately 61-70\% phosphorus found in poultry diet ingredients is in the form of phytate phosphorus. Some microorganisms do produce phytase, most frequently the Aspergillus genus. The monogastric animals like poultry birds are unable to utilize this phytate phosphorus, as they lack endogenous phytase, which necessitates in the addition of inorganic feed containing phosphates to poultry diets in order to meet the phosphorus requirements of poultry ( $\mathrm{Yu}$ et al.,, 2004). Phytase in poultry diets improves gut health as indicated by reduced secretions from the gastrointestinal tract (GIT) which consequently improves the efficiency of utilization of energy. The main objective of this current review therefore is to determine the effect of dietary phytase feed additives on the broiler performance. Many studies showed that microbial phytase can be used to increase the availability of $\mathrm{P}$ and reduce its excretion (Waldroup et al., 2000; Paik, 2003). Previous studies have mainly focused on the 
utilization of 3-phytase (EC 3.1.3.8) derived from the Aspergillus niger (Panda et al., 2007) as feed additives for broilers.

Phosphorus (P) is an essential mineral for growth and skeletal development in chickens and if deficient results in deleterious effects such as skeletal deformities and impaired metabolic processes and ultimately poor nutrient utilization and decreased performance (Scott et al., 1982). As P plays an important role in the metabolism of primary nutrients, so its deficiency results in poor health and performance of chickens (Waldroup, 1999; Hatten et al., 2001). Conventional vegetable feed sources have low (up to 30-40\%) availability of $\mathrm{P}$ (Nelson, et al., 1968; NRC, 1994), as P is in bound form phytate. Non-ruminants lack the endogenous enzyme for the hydrolysis of phytate, so there is a need for supplementation of inorganic $\mathrm{P}$ (di-calcium phosphate, DCP) to overcome the $\mathrm{P}$ deficiency (Sebastian et al., 1998). Phytate binds amino acids by the formation of binary protein-phytate complexes in the gastrointestinal tract. These complexes are resistant to pepsin activity. Phytate has also been reported to promote the flow of endogenous amino acids (Thompson, 1988).

\section{Materials and Methods}

The trial was conducted in summer season at the poultry farm situated at Agriculture farm of the Institute of Agriculture Sciences, Banaras Hindu University, Varanasi221005(India). Two hundred ten (210) of one day-old commercial broiler chicks (VenCobb$500)$ were divided into five groups $\left(T_{0}, T_{1}, T_{2}\right.$, $\mathrm{T}_{3} \& \mathrm{~T}_{4}$ ) of 42 birds in each with fifteen replicate of 14 broilers in each. The birds of $\left(\mathrm{T}_{1}, \mathrm{~T}_{2}, \mathrm{~T}_{3} \& \mathrm{~T}_{4}\right)$ groups were feed with basal diets having (250FTU, 500FTU, 750FTU \& $1000 \mathrm{FTU} / \mathrm{kg}$ ) respectively, while $\mathrm{T}_{0}$ group was feed without any phytase. The birds were kept under deep litter system. At the start of the experiment the broiler starter ration was fed from one day to 21 days containing $23 \%$ $\mathrm{CP}$ (Crude protein) and $2900 \mathrm{Kcal} / \mathrm{ME} / \mathrm{kg}$ of ration. Further broiler per-starter ration containing 20\% CP (Crude protein) and 3000 $\mathrm{Kcal} / \mathrm{ME} / \mathrm{kg}$ was giving from 22 days to 42 days age chicks (Table 1). Self-compounded phytase enzyme was mixed at (250FTU, 500FTU, 750FTU \& 1000FTU/kg) of broiler starter and broiler per-starter ration in $\left(\mathrm{T}_{0}, \mathrm{~T}_{1}\right.$, $\mathrm{T}_{2}, \mathrm{~T}_{3} \& \mathrm{~T}_{4}$ ) groups respectively. The control group $\left(\mathrm{T}_{0}\right)$ was feed broiler starter and broiler per-starter ration without any phytase enzyme.

\section{Determination of serum calcium and phosphorus}

\section{Calcium procedure}

$2.0 \mathrm{ml}$ sample of clear blood serum was transferred by means of a pipette to a $250 \mathrm{ml}$ Erlenmeyer flask. The sample was diluted to $50 \mathrm{ml}$ with calcium-free distilled water. $0.4 \mathrm{ml}$ of $9 \mathrm{~N} \mathrm{KaOH}$ solutions and 1 drop of ammonium purported indicator was added. The 36 sample was rapidly titrated with constant swirling to the same purple end-point reached in a titrated blank (Elliott, 1952)

\section{Phosphorus procedure}

Three $\mathrm{ml}$ of a suitable dilute standard or sample was measured into a calibrated Klett tube. $0.5 \mathrm{ml}$ of 1: 2 nitric acids was added and mixed by thorough shaking. Then $0.5 \mathrm{ml}$ of 0.25 per cent ammonium vanadate solution was added and mixed by shaking. Finally 0.5 $\mathrm{ml}$ of 5 per cent ammonium molybdate, made to a volume of $5 \mathrm{ml}$ with water, and mix by inversion. After the mixture has stood for 5 minutes, it was read in the calorimeter with the No. 42 (blue) filter. A blank was prepared with $3 \mathrm{ml}$. of 7.5 per cent trichloroacetic acid and the reagents added in the same amounts and ordered as the standard. In every case the calculations were based upon the reading after subtraction of the blank reading (Klett, 1952). 


\section{Bone mineral analysis}

Six birds were selected based on the group mean weight for the bone mineral analysis. The tibia bones of the selected birds were removed carefully from the thigh and the fresh bones oven dried at $100^{\circ} \mathrm{C}$ to obtain a constant weight. The dry bones were ashed at $550^{\circ} \mathrm{C}$ for 6 hours to obtain the ash content of the bone. The bone ash was analyzed for calcium; phosphorus and zinc content using Atomic Absorption Spectrophotometry (AAS). Finally, the data analysis by programmer (SAS, 2004) software version 9.1 (SAS, Cary, NC) using general linear model (GLM) significant differences among treatment means are separated using C.D. method.

\section{Results and Discussion}

Towards the end of trial the tibia characteristics parameters dry ash (\% of live wt.), Ash \% minerals, (zinc, Calcium and Phosphorus \% of ash) in right leg ash of broiler chickens under different treatments in $6^{\text {th }}$ week which after slaughtered at summer season in. The effects of phytase supplementation at different levels on minerals content of tibia bone of birds are summarized in Table 2 showed significant difference ( $>0.05)$ among treatments These results are supported with Ravindran et al., (1995), Sebastian et al., (1996b), Mitchell and
Edwards (1996), Qian et al., (1997), Cabahug et al., (1999) and P. K. Singh et al.,(2003) and, for Dry weight of tibia (\% of live weight), phytase supplementation improved the weight of tibia and ash percentage. It was maximum at summer season $(11.79 \%$ and $52.22 \%$ respectively, in phytase supplemented diets having high phytase enzyme 1000FTU/kg. Phytase supplementation increased maximum of minerals (Ca, P and Zinc \% of ash) (43.85, 61.80 and $20.69 \%$ of ash) respectively at summer season from the high phytase supplementation at T4 (1000FTU/kg).

The tibia ash concentrations of the birds feed on control and high phytase diets were significantly $(p>0.05)$ different. The highest tibia ash were recorded in birds feed on the high phytase supplementation at $\mathrm{T} 4$ $(1000 \mathrm{FTU} / \mathrm{kg})$. These results were similar with other reports Yan et al., (2000), Viveros et al., (2002), Shirley and Edwards (2003), Saima et al., (2009) and walk et al., (2014). The data revealed that application of phytase enzyme during summer season was combination showed significant difference $(\mathrm{P}<0.05) \quad$ effect tibia characteristics parameters, dry ash (\% of live wt.), Ash \% minerals, (zinc, calcium and phosphorus $\%$ of ash) in right leg ash of broiler chickens at all the treatments of supplementation phytase enzyme compared with control treatment of observation during summer season.

Table.1 Chemical composition of broiler feed

\begin{tabular}{|c|c|c|c|}
\hline \multirow[t]{2}{*}{ No. } & \multirow[t]{2}{*}{ Specification } & \multicolumn{2}{|c|}{$\begin{array}{c}\text { Percentage } \\
\end{array}$} \\
\hline & & Broiler Starter & Broiler per-Starter \\
\hline 1. & Crude protein & 23.0 & 20.0 \\
\hline 2. & Crude fiber & 5.0 & 5.0 \\
\hline 3. & Calcium & 1.0 & 1.0 \\
\hline 4. & Phosphorus & 0.5 & 0.5 \\
\hline 5. & Lysine & 1.22 & 1.06 \\
\hline 6. & Methionine & 0.83 & 0.72 \\
\hline 7. & M.E. & $2900 \mathrm{kcal} / \mathrm{kg}$ & $3000 \mathrm{kcal} / \mathrm{kg}$ \\
\hline
\end{tabular}


Table.2 Effect of phytase enzyme supplementation on bone mineralization of broiler chickens in summer season

\begin{tabular}{|c|c|c|c|c|c|c|}
\hline Parameters & \multicolumn{5}{|c|}{ Treatments } & \multirow{2}{*}{$\begin{array}{l}\text { C.D. at } \\
5 \%\end{array}$} \\
\hline Tibia characteristics: & T0 & T1 & T2 & T3 & T4 & \\
\hline Dry weight (\% of live wt.) & 7.69 & 8.48 & 8.97 & 10.50 & 11.19 & 3.5 \\
\hline Ash \% of MD & 47.36 & 49.86 & 50.65 & 50.95 & 53.22 & 5.9 \\
\hline Calcium (\% of ash) & 36.13 & 40.36 & 42.51 & 43.62 & 43.85 & 7.7 \\
\hline Phosphorus(\% of ash) & 39.81 & 46.50 & 55.48 & 58.21 & 61.80 & 22.0 \\
\hline Zinc (\% of ash) & 15.80 & 18.20 & 18.81 & 19.56 & 20.69 & 4.89 \\
\hline
\end{tabular}

T0 (Control (Standard feed), T1 (Standard feed+ 250FTU/kg), T2 (Standard feed+ 500FTU/kg), T3 (Standard feed+ $750 \mathrm{FTU} / \mathrm{kg}$ ), T4 (Standard feed+1000FTU/kg).

Table.3 Effect phytase enzyme on biochemistry parameters minerals (Calcium and Phosphorus $\mathrm{mg} / \mathrm{dl})$ in blood serum of broiler chickens

\begin{tabular}{|l|l|l|l|c|c|c|l|}
\hline \multirow{2}{*}{ Season } & Parameters & \multicolumn{5}{|c|}{ Treatments } & C.D. at \\
\cline { 3 - 8 } & & \multicolumn{1}{|c|}{ T0 } & T1 & T2 & T3 & T4 & 5\% \\
\hline \multirow{2}{*}{$\begin{array}{l}\text { Summer } \\
\text { season }\end{array}$} & Calcium mg/dL & $\mathbf{8 . 1 5}$ & $\mathbf{9 . 4 8}$ & $\mathbf{1 0 . 3 3}$ & $\mathbf{1 0 . 8 0}$ & $\mathbf{1 1 . 3 3}$ & $\mathbf{3 . 1 8}$ \\
\cline { 2 - 8 } & Phosphorus mg /dL & $\mathbf{3 . 1 5}$ & $\mathbf{3 . 9 0}$ & $\mathbf{4 . 3 7}$ & $\mathbf{5 . 4 1}$ & $\mathbf{5 . 5 1}$ & $\mathbf{2 . 3 6}$ \\
\hline
\end{tabular}

T0 (Control (Standard feed), T1 (Standard feed+ 250FTU/kg), T2 (Standard feed+ 500FTU/kg), T3 (Standard feed+ 750FTU/kg), T4 (Standard feed+1000FTU/kg).

The data revealed that application of phytase enzyme during summer season was combination showed significant difference $(\mathrm{P}<0.05)$ on biochemistry parameters minerals (Calcium and Phosphorus $\mathrm{mg} / \mathrm{dl}$ ) in blood serum at all the treatments of supplementation phytase enzyme compared with control treatment of observation during summer season. Assay of biochemical indicator from blood serum is shown in Table 3. Compared with the $\mathrm{T}_{0}$ control group broilers, the treatments supplemented phytase increased significant $(\mathrm{P}<0.05)$ the serum phosphorus. Serum phosphorus $\mathrm{m}$ of treatment $\mathrm{T}_{4}$ and $\mathrm{T}_{3}$ broilers was higher than that of treatment $T_{2}$ and $\mathrm{T}_{1}$ on broilers $(\mathrm{P}<0.05)$. This was similar to results by Dendow et al., (1995). There was no significant difference $(\mathrm{P}>0.05)$ between treatments $T_{4}$ and $T_{3}$ on serum phosphorus of broilers. Serum calcium increased with treatments phytase increasing in diets compared with $\mathrm{T}_{0}$ control. Serum calcium of treatment $T_{4}$ and $T_{3}$ broilers was higher than that of treatment $\mathrm{T}_{2}$ and $\mathrm{T}_{1}$ broilers $(\mathrm{P}<0.05)$.
Regarding to the serum alkaline phosphatase, calcium of broilers receiving phytase, there was no significant difference $(\mathrm{P}>0.05)$ between treatments $T_{4}$ and $T_{3}$ of broilers. Peng Ying et al., (2011) and Mohamed et al., (2014) got the same results when they studied the effects of phytase on the performance and calcium and phosphorus metabolism of AA broilers by supplementing phytase in low $\mathrm{P}$ diets. Serum calcium increased along with the used of serum phosphorus and the high concentration of serum was beneficial to the use of phytase.

\section{References}

Cabahug, S., V. Ravindran, P. H. Selle and W. L. Bryden. 1999. Response of broiler chickens to microbial phytase as influenced by dietary phytic acid and non-phytate phosphorus levels. I. Effects on bird performance and toe ash content. Brit. Poult. Sci. 40:660-666.

Camden, B.J., Morel, P.C.H., Thomas, D.V., 
Ravindran, V. and Bedford, M.R. (2001). Effectiveness of exogenous microbial phytase in improving the bioavailabilities of phosphorus and other nutrients in maize- soyabean meal diets for broilers. Animal Science. (73): 289-297.

Ciftci, M., Bestami D. and M. Ali Azman, M. (2005) Effects of microbial phytase supplementation on feed consumption and egg production of laying hens. International Journal of Poult. Science. 4 (10): 758-760.

Coelho, M. B., and E. T. Kornegay. (1996). Phytase in Animal Nutrition and Waste Management. BASF Corp., Mt. Olive, NJ.

Coelho, M.B. and Kornegay E.T. (1999). Phytases in Animal Nutrition and Management: A Practical Reference Manual. 2nd rev. ed. BASF Monograph Series. BASF Corp., Parsippany, NJ. Cosgrove, D. J., (1966). The chemistry and biochemistry of inositol polyphosphates. Rev. Pre Appl.

Cowieson, A. J., Acamovic, T., and Bedford, M. R. (2006). Supplementation of cornsoy-based diets with an Eschericia coliderived phytase: effects on broiler chick performance and the digestibility of amino acids and metabolizability of minerals and energy. Poultry Science, 85(8), 1389-1397.

Cowieson, A. J., and O. Adeola. (2005). Carbohydrase, protease, and phytase have an additive beneficial effect in nutritionally marginal diets for broiler chicks. Poult Sci. 84:1860-1867.

Cowieson, Aaron J., Helen Masey-O’Neill, and Michael R. Bedford. (2012). "Enzymes beyond phytase in poultry nutrition."

Edwards, H.M., Carlos, A.B., Kasim, A.B., Toledo, R.T., (1999). Effects of steam pelleting and extrusion on phytate phosphorus utilization in broiler chickens. Poultry Science. (78), 96-101. Ghorbani, M. R., J. Fayazi, and M. Chaji. (2009). Effect of dietary phytase and NSP-degrading enzymes in diets containing rape seed meal on broiler performance and carcass characteristic. Res J Bio Sci. 4(3):258-264.

Gracia, M. I., M. J. Aranibar, R. Lazaro, P. Medel, and G. C. Mateos. (2003). $\alpha$ Amylase supplementation of broiler diets based on corn. Poult Sci. 82:436442.

Hajati, H., (2010). Effects of enzyme supplementation on performance, carcass characteristics, carcass composition and some blood parameters of broiler chicken. Am. J. Anim. Vet. Sci., 5: 221-227. DOI 10.3844/ajavsp.2010.221.227.

Huber, K., Zeller, E., and Rodehutscord, M. (2015). Modulation of small intestinal phosphate transporter by dietary supplements of mineral phosphorus and phytase in broilers. Poultry Science, 94(5), 1009-1017.

Powell, S., S. Johnston, L. Gaston, and L. L. Southern. 2008. The effect of dietary phosphorus level and phytase supplementation on growth performance, bone- breaking strength, and litter phosphorus concentration in broilers. Poult Sci. 87:949-957.

Qian, H., H. P. Veit, E. T. Kornegay, V. Ravindran, and D. M. Denbow. (1996). Effects of supplemental phytase and phos-phorus on histological and other tibial bone characteristics and performances of broilers fed semipurified diets. Poult. Sci. 75:618-626.

Ravindran, V., Cabahug, S., Ravindran, G., Selle, P.H., Bryden, W.L., (2000). Response of broiler chickens to microbial phytase supplementation as influenced by dietary phytic acid and non-phytate phosphorus levels. II. Effects on apparent metabolisable 
energy, nutrient digestibility and nutrient retention. British Poultry Science. (41), 193-200.

Ravindran, V., E. T. Kornegay, D. M. Denbow, Z. Yi, and R. M. Hulet. (1995b). Response of turkey poults to tiered levels of Natuphos phytase added to soybean meal-based semi-purified diets containing three levels of nonphytate phosphorus. Poult Sci. 74:1843-54.

Saima, M. Z. U. Khan, M. A. Jabbar, M. Ijaz* and M. A. Qadeer, (2009). EFFICACY OF MICROBIAL PHYTASE AT DIFFERENT LEVELS ON GROWTH PERFORMANCE AND MINERAL AVAILABILITY IN BROILER CHICKEN. Journal of Animal \& Plant Sciences 19(2): 2009, Pages: 58-62.

Singh, P.K., V. K. Khatta, R. S. Thakur, S.
Dey and M. L. angwan,(2003). Effects of Phytase Supplementation on the performance of Broiler Chickens Fed Maize and Wheat Based Diets with Different Levels of Non-phytate Phosphorus. (Asian-Aust. J. Anim. Sci. 2003. Vol 16, No. 11: 1642-1649

Walk, C. L., Santos, T. T., and Bedford, M. R. (2014). Influence of superdoses of a novel microbial phytase on growth performance, tibia ash, and gizzard phytate and inositol in young broilers. Poultry Science, 93(5), 1172-1177.

Yan, F., J. H. Kersey, C. A. Fritts, and P. W. Waldroup. (2003). Phosphorus requirements of broiler chicks six to nine weeks of age as influenced by phytase supplementation. Poult Sci. 82:294- 300.

\section{How to cite this article:}

Ebrahim Mohammed Hussein Alarasi and Pandey, R.K. 2017. Influence of Microbial Phytase on Tibia Characteristics and Biochemistry in Blood Serum of Broiler Chickens. Int.J.Curr.Microbiol.App.Sci. 6(11): 2757-2762. doi: https://doi.org/10.20546/ijcmas.2017.611.326 